\title{
KINERJA APARATUR TERHADAP KUALITAS PELAYANAN PUBLIK DI KANTOR KELURAHAN WALA KECAMATAN MARITENGNGAE KABUPATEN SIDENRENG RAPPANG
}

\author{
1)Nur Syawal Ashari, 2)Muhammad Rais Rahmat, ${ }^{3)}$ Abdul Jabbar \\ Fakultas IImu Sosial dan IImu Politik Universitas Muhammadiyah Sidenreng Rappang \\ Nursyawalashari19@gmail.com
}

\begin{abstract}
Abstrak
Kinerja Aparatur Terhadap Kualitas Pelayanan Publik Di Kelurahan Wala Kecamatang Maritengngae Kabupaten Sidenreng Rappang. Populasi dalam melakukan penelitian ini yaitu masyarakat dengan jenis kelamin laki-laki dan perempuan yang berjumlah 3,725 jiwa dari dua lingkungan, teknik pengumpulan data yang digunakan yaitu Rumus Slovin dengan hasil 92 orang, diambil berdasarkan teknik purposive sampling. Tipe penelitian yang digunakan yaitu penelitian deskriptif kuantitatif, Teknik pengumpulan data yang digunakan yaitu teknik observasi, kuesioner, studi kepustakaan, dan dokumentasi. Teknik analisis data yaitu menggunakan uji validitas, reliabilitas dengan menggunakan bantuan aplikasi SPSS 21.0 for window dan Skala Likert. Berdasarkan penelitian yang diambil dari hasil olah data kuesioner diperoleh rekapitulasi variabel Kinerja Aparatur dengan persentase 67,4\% termasuk dalam kategori "Baik" sedangkan rekapitulasi variabel Kualitas Pelayanan Publik dengan persentase 69,6\% termasuk dalam kategori "Baik".
\end{abstract}

Kata kunci: Kinerja Aparatur dan Kualitas Pelayanan Publik.

\begin{abstract}
Apparatus on the quality of public services in Wala Village, Kecamatang Maritengngae, Sidenreng Rappang Regency. The population in conducting this study were people with male and female gender, amounting to 3,725 people from two environments, the data collection technique used was the Slovin formula with 92 results, taken based on purposive sampling technique. The type of research used is descriptive quantitative research, data collection techniques used are observation techniques, questionnaires, literature study, and documentation. The data analysis technique is using the validity and reliability tests using the SPSS 21.0 application and a Likert scale. Based on the research that was taken from the results of the questionnaire data, it was obtained that the recapitulation of the Apparatus Performance variable with a percentage of $67.4 \%$ was included in the "Good" category while the recapitulation of the Public Service Quality variable with a percentage of $69.6 \%$ was included in the "Good" category.
\end{abstract}

Keywords: Apparatus Performance and Quality of Public Services.

PRAJA| Volume 8| Nomor 3| Edisi Oktober 2020 


\section{A. PENDAHULUAN}

Pemerintah mempunyai peranan penting untuk menyediakan layanan publik yang prima bagi semua penduduknya sesuai yang telah diamanatkan. Keputusan Menteri Pendayagunaan Aparatur Negarah No: 63/KEP/M.PAN/7/2003 mendefniskan pelayanan publik sebagai "segala bentuk pelayanan yang dilaksanakan oleh institut pemerintah di pusat, di daerah dan lingkungan badan usaha milik negara,badan usaha milik daerah dalam bentuk barang dam jasa, baik dalam rangka pemenuhan kebutuhan maupun dalam rangka melaksanaka ketentuan peraturan perundang -undangan". Menurut Pasolong (2010:128), pelayanan pada dasarnya didefinisikan sebagai aktifitas seseorang, sekelompok dan/atau organisasi baik secara langsung maupun tidak langsung untuk memenuhi kebutuhan. Dari pengertian diatas dapat dikutip bahwa dalam suatu pelayanan terdapat dua aspek yaitu seseorang atau organisasi dan pemenuhan kebutuhan. Kemudian menurut pandangan Dalam konteks ini pelayanan dititikberatkan kepada suatu elemen administrasi publik memanfaatkan guna mengsukseskan pemberian suatu pelayanan publik. Dan salah satu yang merupakan bentuk pelaksana pelayanan publik adalah administrasi kependudukan yang berada disuatu pemerintahan.

Pegawai negeri sipil adalah unsur aparatur birokrasi adbi negaradan masyaraka. Pelayana merupakan tugas pokok dari apartur sebaga abdi negara dan masyarakat.Tugas ini tela dijelaskan dalan UUD 1945 alinea kempat, yaitu "melindungi segenap bangsa dan seluruh tumpah dara indonesia, memajukan kesejahtraan umum, mencerdaskan kehidupan bangsa dan melaksanakan ketertiban dunia yang berdasar kemerdekaan, perdamaian abadi dan keadilan sosial". Sebagai aparatur birokrasiberarti pegawai negerisipil adalah alat pemerinta untuk mencapai tujuan sebagai aparatur harusmengabdi pada negara danmasyarakat. Olehkarena itu, sudahsepastinya pegawai negerisipil melakukan pelayanan terhadap masyarakat.

Namun pada kenyataan pemerintah kelurahan sebagai salah satu instasi pemberi layanan di Kantor Kelurahan Wala masih terdapat kelemahannya sehinga belum memnuhi kualitas pelayanan yan dharapkan oleh masyaraka, haltersebut ditandaidengan beberapa keluhan-keluhan dari masyaraka. Berdasarkan dari hasil observasi awal calon peneliti yang dilakukan pada tanggal 23 Desember 2019 di Kelurahan Wala Kecamatan Maritenggngae Kabupaten Sidenreng Rapxxang bahwa penyelengaraan pelayanan yang dilakukan pegawai dalam salah satu pelayanan pengurusan surat pengantar kartu tanda penduduk atau sebagainya yang kurang lancar dan terkendala disebabkan karena pegawai kadang terlambat masuk kantor atau pulang lebih awal dari waktu yang ditentukan kemudian mementingkan urusan pribadi diluar dari urusan kantor. Terbukti dengan dilanjutkannya wawancara dengan ibu Angrani yang menyatakan bahwa ketika saya ingin melakukan pembuatan surat pengantar Kartu Tanda Penduduk (ktp) baru kurang lancar karena staf yang bersangkutan tersebut sering terlambat atau sedang tidak berada di kantor karena ada urusan pribadi diluar dari urusan kantor yaitu mengikuti acara keluarga. sedangkan saya sudah berada di kantor sekitas jam 8:30.

Peraturan Bupati Sindenreng Rappang (PERBUP) Nomor 23 Tahun 2017 tentang hari kerja dan jam kerja aparatur sipil negara di lingkungan pemerintah Kabupaten Sidenreng Rappang hari kerja dan jam kerja terdapat pada Pasal 4 ketentuan jam kerja yang dimaksud Pasal 3 ditetapkan sebagai berikut : a). Hari Senin, Selasa, Rabu dan Kamis pukul 08.00 wita s/d 16.30 wita. b). Hari jum'at pukul 08.00 wita s/d 17.00 wita. Hal ini juga menyebabkan pegawai masih kurang bertangung jawab terhadap tugas dan tanggun jawab yang diamanatkan kepadanya seperti terlihat masih banyaknya pegawai suka melalaikan pekerjaannya. tak jarang juga ada masyarakat yang pulang karena syarat-syarat untuk mendapat pelayanan belum lengkap dikarenakan tidak adanya tanda yang menunjukan prosedur, atau proses playanan.

Berdasarkan hal diatas dapat diuraikan bahwa masih adanya ketidak sesuaian pelayanan apa yang diberikan dan yang diinginkan masyarakat. Pelayanan di Kelurahan harus ditingkatkan sebagai pemberi pelayanan. Pada dasarnya masyarakat berhak untuk mendapat pelayanan yang terbaik dari pemerintah 
sebab masyarakat telah memberikan dananya dalam bentuk pembayaran pajak, retribusi dan berbagai pungutan lainnya. Pentingnya hubungan kerja sama yang baik antara aparat dengan masyarakat dalam penerima dan pemberi dalam suatu pelayana publik.

Uraian latar belakan masalah maka penulis merasa perlu mengadakan penelitian dengan judul kinerja Aparatur terhadap kualitas pelayanan publik di Kantor Kelurahan Wala Kecamatan Maritengngae Kabupaten Sidenreng Rappang dengan tujuan untuk mengetahui kinerja aparatur diKelurahan Wala Kecamatang Maritengngae Kabupaten Sidenreng Rappang, untuk mengtahui kualitas pelayanan publikdiKelurahan Wala Kecamatang Maritengngae Kabupaten Sidenreng Rappang, dan untuk mengetahui kinerja aparatur terhadap kualitas pelayanan publik diKelurahan Wala Kecamatang Maritengngae Kabupaten Sidenreng Rappang.

Moeheriono (2009: 66) menyatakan bahwa kinerja adalah suatu pekerjaan yang dapat duhasilkan oleh seseoran atausekelompok orang dalan suatuorganisasi baiksecara kuantiatif maupunkualitatif, sesuai dengan kewenangan dan tangungjawab masingmasing, upaya untuk mencapai tujuan secara legal dantidak melangar hukum. uraian diatas dapat disimpulka bahawa kinerja ini merupakan hasil,atau prestasi dilakkukan oleh individu maupun kelompok dengan melakukan proses pekerjan dengan tangun jawab yang diberilkan kepadanya dengan hasil yan dicapai. Kinerja merupakan terjemahan dari kata performance mengandung beberapa pengertian antara lain

1. melaksanakan,menjalankan Melakukan, (todo,orcarryout, execute).

2. melaksanakan atau Memenuhi kewajiban suatu niat atau nazar (to dischargeof fulfill; asvow ).

3. Melakuka sesuatu yan diharapka oleh orang atau mesin ( to do what isexpected of a person machine )

Menurut Keban (2004: 109) dan Pasolong (2010:184) mengukur kinerja pegawai penting dilakukan oleh instansi pelayanan publik. Sedangkan Menurut Flippo (2005:28) kualitas kerja adalahsuatu hasil yang dapat diukur dengan efektifitas dan efisiensi suatu pekerjaan yang dilakukan oleh sumber daya manusia atau sumberdaya lainnya dalam pencapaian tujuan atau sasaran perusahaan dengan baik danberdaya guna. Mitchel dalam buku Serdamayanti (2001: 51) yang berjudul manajemen sumber daya manusia dan produktivitas kerja, mengemukakan indikatorindikator kinerja tersebut yaitu sebagai berikut :

1. Kualitas kerja (quality of work). Kualitas kerja yang dicapai berdasarkan syaratsyarat kesesuaian dan kesiapannya yang tinggi pada giliranya akan melahirkan penghargaan dan kemajuan serta perkembangan organisasi melalui peningkatan pengetahuan dan keterampilan secara sistematik sesuai tuntunan ilmu pengetahuan dan teknologi yang semakin berkembang pesat. Kualitas kerja adalah suatu hasil yang dapat diukur dengan efektifitas dan efisiensi suatu pekerjaan yang dilakukan oleh sumber daya manusia atau sumber daya lainnya dalam pencapaian tujuan atau sasaran perusahaan denga baik dan berdaya guna (Kartika, 2016).

2. Ketetapanwaktu (pomptnees). Berkaitan dengan sesuai atau tidaknya waktu penyelesaian pekerjaan dengan target waktu yang direncanakan. Setiap pekerjaan diusahakan untuk selesai dengan rencana agar tidak menggangu pada pekerjaan lain.

3. Inisiatif (initiative). Yaitu mempunyai kesadaran diri untuk melakukan sesuatu dalam melaksanakan tugas-tugas dan tanggun jawab. bawahan atau pegawai dapat melaksanakan tugas tanpa harus bergantung terus menerus kepada atasan.

4. Kemampuan (capability). Yaitu diantara beberapa faktor yang mempengaruhi kinerja seseorang, ternyata yang dapat diintervensi atau diterapi melalui pendidikan dan latihan adalah faktor kemampuan yang dapat dikembangkan.

5. Komunikasi (communication). Merupakan mengemukakan saran dan pendapatnya dalam memecahkan masalah yang dihadapi oleh atasan kepada bawahan. Komunikasi menimbulkan rasa kerjasama yang lebih baik dan hubungan - hubungan yang harmonis diantara para atasan dan bawahan, yang dapar juga menimbukan rasa senasi sepenangungan.

Kelurahan merupakan prangkat daerah Kabupaten/Kota yang berkedudukan 
diwilayah kecamatan. Kelurahan dipimpin oleh Lurah yang berada dibawah dan bertanggung jawab kepada Bupati/ Walikota melalui Camat Lurah diangkat oleh Bupati/ Walikota Camat dari Pegawai Negeri Sipil. Lurah melaksanakan urusan pemerintahan yang dilimpahkan oleh Bupati/ Walikota. Urusan pemerintahan desesuaikan dengan kebutuhan kelurahan dengan memperhatikan prinsip efisiensi dan peningkatan akuntabilitas.

Undang-Undang Nomor25tahun 2009 tentangPelayanan Publik, ditegaskan dalam Pasal 1butir 1: "Pelayanan publik adalah kegiatan atau rangkaiang kegiatan dalam rangka pemenuhan kebutuhan pelayanan sesuai dengan peraturan perundangundangan bagi setiap warga negara dan penduduk atas barang, jasa dan/atau pelayanan administratif yang dielenggarakan oleh penyelenggara pelayanan publik". Menurut Brady dan Conin dijelaskan bahwa "kualitas pelayanan merupakan perbandingan antara kenyataan atas pelayanan yang diterima dengan harapan atas pelayanan yang ingin diterima". Sedangkan ditambahkan oleh Parasuraman, Zeithaml,dan Berrydalam (Samosir, 2005, h.28 "kualitas pelayanan adalah perbandingan yang diharapkan konsumen dengan pelayanan yang diterimanya". Mahmudi 2010 (Sellang, 2016) menyatakann bahwa pelayanan publik merupakan segalabentuk kegiatan pelayana yang diilaksanakan oleh penyelenggara pelayanan publik sebagaiupaya pemenuhan kebutuhan publik dan pelaksanaan ketentuan peraturan perundang-undangan.

Hakekat Pelayanan Publik antara lain :

1. Meningkatkan mutuh dan produktifitas pelaksaaan tugasdan fungsipemrintahan dibidang pelayana publik.

2. Mendoron upaya mengefektivkan sisten dan tatalaksana pelayana, sehinga pelayanan publik dapat diselengarakan lebih berdayah gunah dan behasil gunah.

3. Mendoron tumbuh kreatifitas, prakasadan peran sertah masyrakat dalam pembangunnan dalan upayah meningkatkannya kesejahteran masyarkat .(Holle, 2011)

Menurut Zeithami-Parasuraman-Berry (Pasolong, 2014), untuk mengetahui kualitas pelayanan yang dirasakan secara nyata oleh masyarakat, ada indikator ukuran kepuasaan yang terletak pada lima dimensi yaitu :

1. Bukti Langsung (Tanngible), yaitu merupakan pengambaran wujud secara fisik dan layanan yang akan diterima oleh konsumen berupa penampilan fasilitas fisik, peralatan, pegawai, dan material yang dipasang.

2. Keandalan (Reliability), yaitu kemampuan untuk memberikan jasa yang dijanjikan dengan handal dan akurat. Jika dilihat dalam pemberiyan layanan surat pengantar kartu tanda penduduk, maka sebuah layanan yang handal adalah ketika seorang karyawan mampu memberikan pelayanan sesuai yang teah dijanjikan dan kemudian membantu penyelesaian masalah yang kemudian dihadapi konsumen dengan cepat.

3. Jaminan (Assurance), yaitu pengetahuan, sopan santun, dan kemampuan karyawan untuk menimbullkan keyakinan dan kepercayaan. Dalam hal ini pemberiyan layanan surat pengantar kartu tanda penduduk, kepastian merupakan menjadi hal penting yang dapat diberi kepada konsumenya, seperti jaminan keamanan dan keselamatan dalam bertransaksi dan kerahasiaan konsumen yang terjamin.

4. Daya Tangap (Responsivenes), yaitu kemauan untuk membantu konsumen dan memberikan jasa dengan cepat. Jika dilihat lebih mendalampada pemberian pelayanan surat pengantaran kartu tanda penduduk dikantor lurah, bisa dilihat dari kemampuan karyawan yang cepat memberikan pelayanan kepada konsumen dan cepat menangani keluhan mereka.

5. Kepedulian atau Empati (Empathy), yaitu kepedulian dan perhatian secara pribadi yang diberikan kepada pelanggan Layanan yang diberikan seperti surat pengantara kartu tanda penduduk oleh para karyawan harus dapat menunjukkan kepedulian mereka kepada konsumen. (Pratama, 2015)

Pada dasarnya ada tiga (3) ketentuan pokok dalammelihat tinggi rendahnyasuatu kualitas pelayananpublik menurutMorgan dan Murgatroyd(Kurniawan 2016) yaitui perlu diperhatikan aadanya keseimbangan antara :

1. Bagianantar pribadi yang melaksanakan, artinya dalam pelaksanaan pelayanan baik oleh pemberi maupun penerima layanan harus saling mengimbangi satu sama lain. 
2. Bagian proses dan lingkungan yang mempengaruhi,artinyadi dalam melaksanakan suatu layanan terdapat proses dan lingkungan yang sangat mempengaruhinya.

3. Bagian profesional dan teknik yang dipergunakan, artinya dalam pelaksanaan pelayanan harus bersifat profesional terhadap teknik yang sedang digunakan.

\section{B. METODE PENELITIAN}

Metode yang digunakan yaitu mengguganakan metode Kuantitatif. Popuasi yang diggunakan dalan penelitian ini adalah keseluruhandari masyarakat kelurahan Wala yang terletak di Kecamatan Maritengngae Kabupaten Sidenreng Rappang yang berjumlah 1,203 jiwa. Dengan jumlah Sampel 92 orang dengan mengunakan teknik purpossive sampling. tekhnik pengumpulan data yang diggunakan ialah obserpasi, kuisioner, studi pustaka, dan documentasi dengan tekhnik analisis data yaitu menggunakan table frekuensi dan SPSS 21.0 for window

\section{HASIL PENELITIAN DAN PEMBAHASAN}

Indikator dalam Kualitas kerja yang digunakan peneliti untuk mengukur bagaimana Kinerja aparatur Di Kantor Kelurahan Wala Kecamatang Maritengngae Kabupaten Sidenreng Rappang terdapat ratarata persentase $67,4 \%$ dari hasil rekapitulasi lima indikator tersebut dengan kategori "Baik", Sedangkan Rekapitulasi Tanggapan Responden Mengenai Indikator Kualitas Pelayanan Publik. Indikator didalam ini yang digunakan oleh untuk menguukur Kualitas Pelayanan Publik diKantor Kelurahan Wala Kecamatang Maritengngae Kabupaten Sidenreng Rappang terdapat rata-rata persentase 69,6 \% dari hasil rekapitulasi kelima indikator tersebut dengan kategori "Baik". Hal ini diperkuat dengan hasil data Model Sumarry, dimana nilai $\mathrm{R}$ Square= 0.482 berarti secara bersama $48,2 \%$ perubahan Kualitas Pelayanan Publik (Y) dapat dijelaskan oleh variabel kinerja aparatur $(X)$, atau dengankata lain pengaru variabel bebasterhadap variabel terikat sebesar $48,2 \%$ sedangkansisanya $51,8 \%$ dipengaruhi olehfaktor lainyang tidakmasuk dalam kerangka penelitian ini.

\section{SIMPULAN}

Berdasarkan hasilpenelitian yangtelah dilakukan, secaraumum dapatdisimpulkan bahwa :

1. Kinerja Aparatur $(X)$ Di Kelurahan Wala Kecamatan Maritengngae Kabupaten Sidenreng Rappang meliputi: Kualitas kerja (quality of work), Ketetapan waktu (pomptnees), Inisiatif (initiative), Kemampuan (capability), Komunikasi (communication). Berdasarkan hasil dengan analisi distribusi frekuensi pada Kinerja Aparatur maka diperoleh rata-rata persentase sebesar $67,4 \%$ atau termasuk dalam kategori baik.

2. Kualitas Pelayanan Publik (Y) Di Kelurahan Wala Kecamatang Maritengngae Kabupaten Sidenreng Rappang, meliputi: Bukti Langsung (Tangible), Keandalan (Reliability), Jaminan (Assurance), Daya Tanggap (Responsiveness), Kepedulian/ Empati (Empathy). Berdasarkan hasil penelitian dengan analisis distribusi frekuensi pada variabel $Y$ (Kualitas Pelayanan Publik) maka diperoleh rata-rata persentase sebesar $69,6 \%$ atau termasuk dalam kategori baik.

3. Hasil analisis dengan regresi linear sederhana dengan bantuan spss versi 20 , .diperoleh bahwa berdasarkan hasil uji $t$, diperoleh nilai t-hitungdari tabel coficient sebesar 9,157 atau lebih besar dari t-tabel, 1,986 dan signifikansi 0,00 atau lebih kecil dari 0,05 . Sehingga dapat disimpulkan bahwa, Kinerja Aparatur berpengaruh/signifikan terhadap Kualitas Pelayanan Publik Di Kelurahan Wala Kecamatang Maritengngae Kabupaten Sidenreng Rappang, frekuensipada variabel $Y$ (partisipasimasyarakat) maka diperoleh rata-ratapersentase sebesar $68,4 \%$ atau dalam kategori baik.

4. Pelaksanaan Musrenbang memberikan pengaruh positif terhadap Partisipasi Masyarakat di Desa Puncak Harapan Kecamatan Maiwa Kabupaten Enrekang hal ini dapat dilihat dari persamaan regresinya yaitu $\mathrm{Y} 1=15.877+0,310 \mathrm{X}$ dan musrenbang berpengaruh signifikan terhadap partisipasi masyarakat. Dibuktikan dari hasil uji $t$ dengan nilai $t_{\text {=hitung }} \geq t_{\text {tabel }}$ atau $5.314 \geq 1.670$ berarti HOditolak dan H1diterima sehingga dapat disimpulkan bahwa pelaksanaan 
musrenbang berpengaruhterhadap partisipasi masyarakat di Desa Puncak Harapan Kecamatan Maiwa Kabupaten Enrekang.

\section{E. REFERENSI \\ Buku}

Pasolong, H. (2014). Teori Administrasi Publik. Bandung: Alfabeta.

Samsuddin,H. (2018). KINERJA KARYAWAN Tinjauan dari Dimensi Gaya Kepemimpinan, Budaya Organisas dan Komitmen Organisasi. indomedia pustaka.

Sellang, K. (2016). Administrasidan Pelayanan Publik Antara Teori dan Aplikasi. Yogyakarta: Penerbit Ombak

Zainuddin. (2017).Teori-Teori Mutakhir DalamPerspektifllmu Administrasi Jurnal

Negara. Makassar: Phinatama Media.

Fahmi reza, siti rochman, S. (2004). ANALISIS PENGARUH KUALITAS PELAYANAN PUBLIK TERHADAP KEPUASAN MASYARAKAT. 1(5), 981990.

Kartika, Y. (2016). Pengaruh Jaminan Sosial Dan Insentif Terhadap Kualitas Kerja Pegawai Biro Bina Kemasyarakatan dan Sosial Kerja pada kantor Gubernur Sumatra Utara. 1-5.

Kurniawan, R.C.(2016). InovasiKualitas PelayananPublikPemerintahDaerah. 10(3), 569-586.

Mirnasari, R. M. (2013). Inovasi Pelayanan PublikUPTD Terminal PurabayaBungurasih.Kebijakan Dan Manajemen Publik, 1, 71-84.

Pratama, M. H. (2015). Strategi Meningkatkan Kualitas Pelayanan Publik (Studi Deskriptif tentang Strategi UPTD Pengujian Kendaraan Bermotor Tandes Kota Surabaya dalam Meningkatkan Kualitas Pelayanan Pengujian Kendaraan Bermotor). Jurnal Kebijakan Dan Manajemen Publik, 3(3),
$90-98$.

Hasdiah;Razak, M.R.R;Darsa, Renil;Adnan, A. . (Universitas M. S. R. (2018). Pengaruh motivasi dan budaya kerja thd Kinerja Pegawai di Kantor Sekretariat Daerah Kabupaten Enrekang. KNAPPPTMA Ke-8, 1-7.

Holle, E. S. (2011). Pelayanan Publik MelaluiElectronic Government UpayaMeminimalisir Praktek MaladministrasiDalam MeningkatanPublic Service Oleh : Erick S. Holle. Sasi, 17(3), 21-30.

Razak, Muhammad Rais Rahmat; B., Sofyan (2020). Role of VillageOwnedEnterprises in Farming CommunityEmpowerment. InternationalJournal ofAdvanced Science andTechnology, 29(6s), 684 691.

Razak, M.R.R.; Ali, Akhwan (2019). Child Social Welfare Institution Participation in the Implementation of Good Governance. Jurnal IImiah IImu Administrasi Publik. Volume 9 Number 2, July- December 2019. Page 345-354 p-ISSN: 2086-6364, e-ISSN: 25497499.

\section{Undang- Undang}

Undang-Undang Nomor25 Tahun2009 Tentang Pelayanan Publik

Undang-Undang Nomor23 Tahun2014 Tentang Pemerintahan Daerah

Keputusan MenteriPendayagunaan Aparaturr Negara Nomor. 63 Tahun 2003tentang Pedoman Umum Penyelenggaraan Pelayanan Publik.

Peraturan Bupati Sindenreng Rappang (PERBUP) Nomor 23 Tahun 2017 tentang hari kerja dan jam kerja. 